\title{
sciendo IMPROVEMENT OF PRODUCTION PROCESSES WITH THE USE OF LEAN MANUFACTURING TOOLS
}

doi:10.2478/mape-2018-0067

Date of submission of the article to the Editor: $03 / 2018$

Date of acceptance of the article by the Editor: 07/2018

MAPE 2018, volume 1, issue 1, pp. 529-535

\author{
PhD., Eng. Joanna Furman \\ PhD., Eng. Marzena Kuczyńska-Chałada \\ MSc., Roksana Poloczek \\ Silesian University of Technology, Poland
}

\begin{abstract}
Growing competition, clients' requirements as well as advances in technology make modern industrial enterprises search for a way of achieving and maintaining strong position on the market. One of the principal and at the same time necessary conditions to achieve this aim is continuous development of all of the processes in order to fulfil various clients' expectations. Enterprises make use of different concepts and management methods which in significant way upgrade ongoing processes by raising their efficiency. One of such is the concept of 'lean' production - Lean Manufacturing. Management according to Lean Management rules allows to produce more with the use of less resources - at the same time approaching the aim which is to deliver clients the exact product they want. The process of resources use limitation is not easy to perform however, the concept of Lean Manufacturing by the application of chosen tools allows successfully and effectively to introduce 'lean' model of management in an enterprise and undertaking following improvement activities in every of its field.
\end{abstract}

Keywords: process improvement, Lean Manufacturing

\section{INTRODUCTION}

The aim of the paper is improvement of a production process in an enterprise with the use of chosen tools of Lean Manufacturing concept. The analysis was carried out in terms of identification of the most common problems that appear in a production process which influence the quality of the final product. Subsequently, particular activities were suggested in order to eliminate them. To analyse Kaizen workshops were used. By the means of Ishikawa diagram the main problems to be solved were defined as well as the reasons of their arising were searched. Afterwards, the classification of the reasons according to their influence on the problem was performed, then 5 Why analysis was carried out - that generated solutions which may contribute to the improvement of the production process in an enterprise. As a result of Kaizen workshops the solutions were suggested implementation of which may improve the ongoing process in the organisation and eliminate defects. To examine the suggested solutions the assessment matrix of speed and costs was applied as well as the matrix of effectiveness (degree of solution influence on problem) and the way of implementation (it is whether an enterprise may launch the solution itself or it has to outsource a different company). Applying the results of both matrixes a set of solutions is created according to their priority. As a research method a case study was chosen in regard of the usefulness of problems solving within processes management in enterprise as well as methods and tools used to make effective and sensible decisions (Piekkari and Welch, 2011). The source of the data was the information handed in by an enterprise and the observations and analysis of the ongoing process. 


\section{CONTINUOUS IMPROVEMENT OF PROCESSES}

The necessity of continuous improvement of an enterprise is a subsequence of permanent and dynamic changes in its surrounding as well as inside it. The key reason of organisation's changes are changes in clients' expectations and requirements regarding products and services as well as in conditions of competition among enterprises which change with time. The result of changing requirements is the complexity of products and their diversity. Simultaneously emerging markets, forms and scope of cooperation make companies to become more flexible and react quickly. Therefore, in the interest of every enterprise, the processes should be shaped and then improved in such a way so to eliminate operations and actions that do not add value to the organisation itself and to improve those actions and processes that add value to the organization and its clients. It is important to have not only efficient processes, but also to create such a relationship between them in order to best meet customer expectations and bring the desired economic effects to the organization.

The basis for the different concepts of process management is the need to improve processes. Lack of activities related to improvement in the long term may lead to disturbances in the management system. Improvement and development of processes that follow changes in the organization's environment may occur in the form of radical or so-called evolutionary transformations. In the first case, we can talk about the restructuring (reengineering) of organizational processes. In the second case - evolutionary changes trigger process improvement, also known as improvement or optimization. Unlike restructuring, it only deals with the components of processes, is oriented towards the inside of the enterprise and intensely involves operational employees who are well aware of the state of the processes carried out in the organization. Its aim is to search for solutions in improving of processes (Nowosielski, 2014).

Continuous improvement of processes is defined as a purposeful action, assuming systematic and continuous development of selected process parameters (time, cost, quality), in the interconnection of these parameters and improved processes. The interconnection of process parameters with simultaneous dependencies between processes allows to define the continuous process of improvement as optimization. This kind of improvement involves using the opportunities inherent in the company's potential and introducing changes that can bring the organization an improvement in the quality of its functioning. There are always ways to improve processes, which means that you need to constantly monitor their progress and continuously improve(Kaizen). The advantage of using continuous process improvement is the increase in productivity and process efficiency, including by reducing their duration, improving timeliness, quality and flexibility, reducing their operating costs (Nogalski, 2010). It should be noted that an important element of process improvement is also the work safe aspect - implemented improvements should include safe working conditions and reduce the number of potential accidents (Małysa, et al., 2017).

Continuous improvement of processes is one of the essential principles of the concept of quality management. The improvement is usually based on a sequence of steps that relate to the measurement, analysis and improvement of products, processes or projects. The methodology of continuously repetitive process improvement is based on Deming cycle (PDCA) based on the analysis of the current state, designing changes and implementation. Continuous improvement of processes underlies many modern concepts and management methods, especially the concept of quality management (TQM), Lean Management and Toyota Production System (TPS). Processes can be improved by means of many solutions among the most popular ones used by enterprises, we can distinguish: 5S method, Kaizen, Six Sigma, FMEA analysis, 5 Why analysis, Poka-Yoke (Urbaniak, 2010).

\section{THE CONCEPT OF LEAN MANUFACTURING}

The Lean Management concept plays an important role in improving processes in the organization. The term Lean Manufacturing (LM) is used for production processes. The term 
"lean" in relation to manufacturing systems means slimming down production in terms of material resources needed, maintained stocks of finished goods and production in progress, and used production halls space. LM therefore describes production systems with a significant degree of "slimming" compared to traditional mass production systems (Wolniak, 2013).

Toyota Production System is considered to be the first lean manufacturing system, where LM's roots are sought. TPS is oriented towards full customer satisfaction, constant search for better methods of improvement and teamwork. The use of this system begins with the analysis of the manufacturing process from the customer's point of view. When analyzing the needs and requirements of the client, the production stages that generate added value should be separated from those that do not increase it, i.e. for which the client does not want to pay, referred to as waste (Furman and Burchart-Korol, 2007). The following categories of waste are distinguished (Bendkowski and Matusek, 2013): overproduction, defects, stocks, improper implementation of processes, unnecessary transport, waiting, unnecessary movements. Lean production gives the opportunity to produce more and more, using less and less - less human effort, devices, time and space - while approaching the goal of providing customers with exactly what they want. This is possible thanks to the reorganization of all company activities: the order of design, administration and executive activities, the organization of material inventory, machine functions and human activities. The concept of Lean Manufacturing is focused on eliminating waste and consists of drawing up a map of activities increasing the value of the product and removing all activities that do not increase it. It is a method of improving the functioning of the company, which through continuous reduction of losses, optimizes the creation and flow of values throughout the production process (Liker, 2005).

\subsection{Lean Manufacturing tools}

The Lean Manufacturing concept offers many useful tools that allow effective and efficient implementation of the "lean" management model in an enterprise, as well as undertaking further improvement activities in each of its areas. A management system based on the Lean concept must be designed in such a way that it takes into account the conditions inside and outside the functioning of the organization, while realizing its vision and mission. The choice of Lean tools depends on the conditions and know-how resources in the enterprise (Kubis, 2005). The basic tools used to improve processes according to the LM concept are (Kuczyńska-Chałada and Furman, 2016): Value Stream Mapping (VSM), 5S method, Kaizen, SMED (Single Minute Exchange of Die) TPM (Total Productive Maintenance). As part of the Lean concept, quality management tools are often used to solve problems improve the productivity, limit wastage and streamline the processes that take place in an organisation (Skotnicka-Zasadzień et al., 2017). The most commonly used are: Ishikawa chart, 5 Why analysis, Pareto-Lorenzo chart. It should be noted that the methods and tools in the field of Lean Manufacturing require employees' involvement and changes in their behaviour and daily work.

\subsection{Kaizen Workshops}

Kaizen workshops are an effective tool in solving problems, involving both management as well as serial employees. The conducted workshops eliminate the barrier between management and operators, through the equal participation of all employees of the company in work on the identified problem or streamlining the process. The most frequently used methodology in conducting Kaizen workshops when the problem is significant is the Ishikawa diagram, which generates possible causes of the problem.

In the first stage the main problem that appeared in the process should be formulated and then the main reasons for its creation defined in five or six categories (man, machine, material, method, management, environment). Then detailed reasons are specified in each category and categorization of causes is performed due to their impact on the problem (category $A$ means a large impact on the problem, category $B$ - medium, category $C$ - small). In the next 
stage of the Kaizen workshops, 5 Why analysis is carried out for the causes that were given category A, generating solutions to the problem. To evaluate the proposed solutions, you can use the speed and implementation cost assessment matrix and the efficiency and implementation matrix - by overlapping the results of two matrices, a set of solutions ranked in priorities is created (Brainstorm Group).

\section{Streamlining the process using Kaizen workshops - case study}

\subsection{Identification of problems in the process}

The analyzed enterprise produces industrial damping. On the basis of detailed observation of the activities carried out in the process, loss areas were identified. The main problem of the production process was the transmission of non-quality semi-finished products to the next stages of the process. During the analysis, all inconsistencies were identified (defects - the second category of waste according to the Lean concept), and then the ones that appeared most often were isolated. The analysis covered a period of three months (February - April 2017). Due to the limited possibility of presenting all data, all inconsistencies were not presented at work. As a result of the analysis, two most frequently repeated non-conformities were identified:

- uneven distribution of glue - in the analysed period in each of three months the noncompliance appeared more than a hundred times (in February 105 times, in March 110 times, in April 118 times),

- uneven material placement (in February - 75 times, in March 80 times, in April 86 times). The total number of all identified non-compliances increased each month and at the end of the study period there were over 800 . Kaizen workshops were carried out to solve the problem.

\subsection{Solution to the problem - Kaizen workshops}

According to the methodology of the Kaizen workshops, the first stage of the improvement consisted of developing Ishikawa chart for the most frequently identified problems (the results presented only for the first non-compliance). The analysis takes into account the causes of defects in five categories, i.e.: people, material, method, machine and management (Fig. 1).

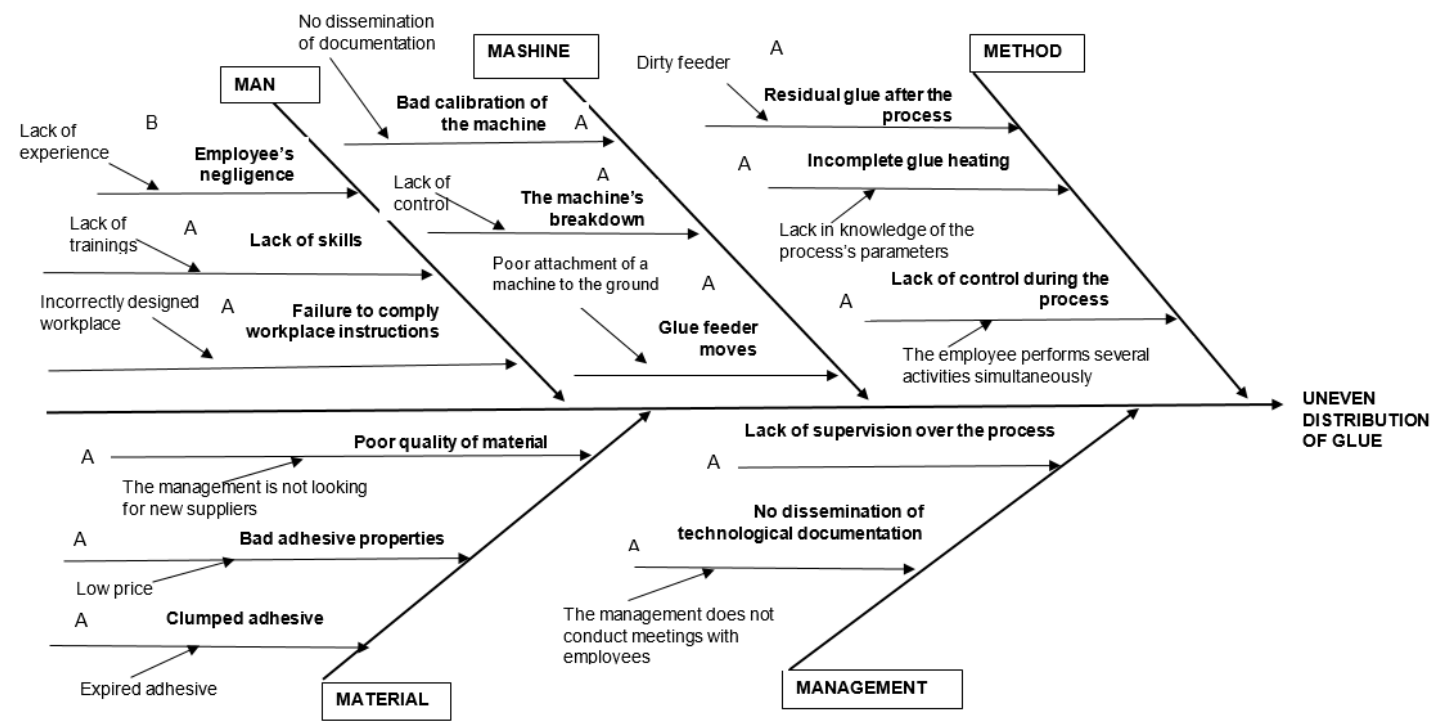

Fig. 1. Ishikawa diagram for the analysed defect 
Table 1

5 Why analysis for the identified defect

\begin{tabular}{|c|c|c|c|c|c|}
\hline \multicolumn{6}{|c|}{ Analysed defect: Uneven distribution of glue } \\
\hline $\begin{array}{l}\text { Main } \\
\text { reasons }\end{array}$ & 1 Why & 2 Why & 3 Why & 4 Why & 5 Why \\
\hline \multirow[b]{2}{*}{ People } & Lack of an employee's skills & Lack of trainings & $\begin{array}{l}\text { Lack of management } \\
\text { awareness }\end{array}$ & & \\
\hline & $\begin{array}{l}\text { An employee did not follow the } \\
\text { workplace instruction }\end{array}$ & $\begin{array}{l}\text { An employee did not notice } \\
\text { the instruction }\end{array}$ & $\begin{array}{l}\text { The instruction was placed } \\
\text { in an invisible place }\end{array}$ & $\begin{array}{l}\text { Wrongly designed } \\
\text { workplace }\end{array}$ & $\begin{array}{l}\text { Lack of management } \\
\text { awareness }\end{array}$ \\
\hline \multirow{3}{*}{ Machines } & $\begin{array}{l}\text { Incorrect calibration of the } \\
\text { machine }\end{array}$ & $\begin{array}{l}\text { Employee's lack of } \\
\text { knowledge of machine's } \\
\text { parameters }\end{array}$ & $\begin{array}{l}\text { An employee did not } \\
\text { receive the instruction }\end{array}$ & Lack of standards & $\begin{array}{l}\text { Lack of management } \\
\text { awareness }\end{array}$ \\
\hline & The machine's breakdown & $\begin{array}{l}\text { Lack of control of } \\
\text { machine's technical } \\
\text { condition }\end{array}$ & $\begin{array}{l}\text { Employees are not obliged } \\
\text { to periodical check }\end{array}$ & & \\
\hline & Glue feeder moves & \begin{tabular}{|l|} 
Machine's vibrations \\
\end{tabular} & $\begin{array}{l}\text { Poor attachment of a } \\
\text { machine to the ground }\end{array}$ & $\begin{array}{l}\text { Not following the guidelines } \\
\text { of the technical and } \\
\text { operational documentation }\end{array}$ & Lack of control \\
\hline \multirow{3}{*}{ Method } & $\begin{array}{l}\text { Residual glue after the previous } \\
\text { process }\end{array}$ & $\begin{array}{l}\text { An employee did not clean } \\
\text { the feeder between } \\
\text { processes }\end{array}$ & $\begin{array}{l}\text { Lack of standards at the } \\
\text { workplace }\end{array}$ & $\begin{array}{l}\text { Lack of management } \\
\text { awareness }\end{array}$ & \\
\hline & Incomplete glue heating & Wrongly set temperature & $\begin{array}{l}\text { Lack of knowledge of basic } \\
\text { process parameters }\end{array}$ & Staff turnover between posts & Shortages in employment \\
\hline & $\begin{array}{l}\text { Lack of control during the } \\
\text { process }\end{array}$ & $\begin{array}{l}\text { An employee forgot } \\
\text { about control }\end{array}$ & $\begin{array}{l}\text { The employee performs } \\
\text { several activities } \\
\text { simultaneously }\end{array}$ & & Savings \\
\hline \multirow{3}{*}{ Material } & Clumped adhesive & \begin{tabular}{|l} 
Glue texture too thick \\
\end{tabular} & $\begin{array}{l}\text { The expiration date of the } \\
\text { adhesive has passed }\end{array}$ & $\begin{array}{l}\text { Inattention of the warehouse } \\
\text { worker }\end{array}$ & $\begin{array}{l}\text { No compliance with the } \\
\text { procedures }\end{array}$ \\
\hline & The use of glue of bad properties & $\begin{array}{l}\text { The purchasing specialist } \\
\text { decided about the choice } \\
\text { of glue }\end{array}$ & Low price & Savings & \\
\hline & Poor quality of material & $\begin{array}{l}\text { Purchase of material from } \\
\text { the same supplier }\end{array}$ & $\begin{array}{l}\text { Contract signed with the } \\
\text { supplier on the product }\end{array}$ & $\begin{array}{l}\text { The management is not } \\
\text { looking for other suppliers }\end{array}$ & $\begin{array}{l}\text { Lack of the problem } \\
\text { awareness }\end{array}$ \\
\hline \multirow[b]{2}{*}{ Management } & $\begin{array}{l}\text { Lack of supervision over the } \\
\text { process }\end{array}$ & Lack of standards & & & \\
\hline & $\begin{array}{l}\text { No dissemination of } \\
\text { technological documentation }\end{array}$ & $\begin{array}{l}\text { The management does not } \\
\text { conduct meetings vith } \\
\text { employees }\end{array}$ & $\begin{array}{l}\text { An outdated approach to } \\
\text { work performance }\end{array}$ & $\begin{array}{l}\text { Lack of management } \\
\text { awareness }\end{array}$ & \\
\hline
\end{tabular}

The next step was to categorize the causes of non-compliance due to the impact on the analyzed problem. For reasons that were given category $A$, the 5 Why analysis was conducted to indicate the root cause of the problem (Table 1).

Based on the analysis of 5 Why, it can be concluded that the main causes of problems related to the two most frequent defects in the process were: lack of standards and lack of awareness on the part of the management. The analysed enterprise is a medium-sized organization in which the technical and organizational level requires significant improvement. The company does not apply Lean Manufacturing solutions that could improve the production process. Many mistakes are made at work - however, a detailed analysis has shown that this is not the cause lying directly on the side of the operators but resulting from the lack of procedures that would define operational activities. Lack of management awareness of the importance of using and following instructions is a serious business problem. Due to the need for savings, management does not systematically organize trainings for employees, which directly transfers to their skills and, as a result, incorrectly performed operations. Lack of procedures also has a negative impact on the technical condition of machines and the quality of work.

\subsection{Proposals and evaluation of solutions}

Based on Kaizen workshops, the following solutions were proposed (using brainstorming method), implementation of which can improve the process of organisation and eliminate defects:

1. Preparation of instructions at workplaces using visual management (the so-called OPL, One Point Lesson), where with the use of images and short descriptions the proper performance of production activities is presented. The instructions should be placed in a visible place for the operator, should be followed by the operator and be a subject of regular control by the process leader. 
2. Preparation of instructions related to the performance of activities in the framework of autonomous maintenance, e.g. cleaning, machine adjustment, visual inspection, etc. The correct performance of activities should be confirmed by the operator's signature (thanks to which the operator becomes responsible for the quality of the process).

3. Development of procedures related to the service activities performed by the maintenance department, which will oblige employees to regularly inspect and preserve machines. This will affect the efficiency of machines and equipment and will ensure the continuity of the process. Instructions developed and approved by management will become standards for compliance by all employees.

4. Conducting short trainings at work places (especially for new employees) by experienced employees or process leaders. Thanks to this, the management does not bear the costs associated with the organization of training during the change.

5. Developing a matrix of competences allowing to monitor employees' skills. In the case of high employee turnover in the enterprise, the matrix is a helpful tool for casting jobs requiring specific skills.

In order to evaluate the proposed solutions, a matrix for assessing the speed and implementation costs as well as the efficiency matrix (the degree of impact of the solution on the problem) and the method of implementation (i.e. whether the organization implements the solution independently or outsource it to an external entity was used). By imposing the results of two matrixes on one another, a set of solutions ranked in priorities arises. Firstly, a solution is implemented that: has a big impact on the problem, can be implemented quickly (e.g. within 1 month), the organization can implement it itself, its costs are low. Fig. 2a-b is the number 1 for the preparation of instructions, number 2 - the solution for conducting training, number 3 development of the competence matrix.

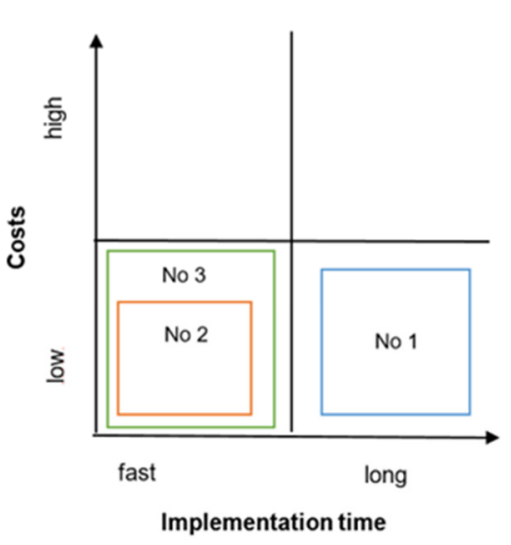

(a)

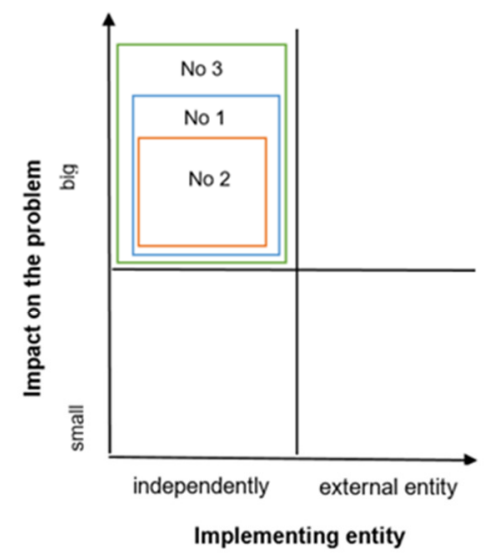

(b)

Fig. 2. The solution implementation matrix

Based on the developed matrix, it can be stated that the priority for the organization is the implementation of solution No. 2 and No. 3. Both solutions can be quickly introduced without incurring any costs. It is enough to involve employees who undertake this task. Next is the implementation of solution No. 1 (preparation of instructions). It is not a difficult task to accomplish as well as it does not require any financial outlays, which is of great importance to the organization. However, it requires a longer time (about 6 months) because it concerns the performance of technological and service activities as well as activities performed by maintenance staff. All proposed solutions have a big impact on the problem, and therefore should be accepted by management and implemented. It is important to fully involve the entire crew, because without the participation of employees, it will not be possible to improve the process. 


\section{CONCLUSION}

As a result of Kaizen workshops, it was found that the main reasons for the inconsistencies are: lack of standards and lack of awareness on the part of superiors. Several solutions have been proposed, implementation of which may improve the process in the organization and eliminate defects, i.e.: development of instructions that (approved, followed and monitored) will become the standard necessary for the proper realisation of the process; developing a matrix of competences as an effective tool for monitoring and improving employees' skills as well as conducting short trainings for operators by experienced employees. The proposed solutions were evaluated using the implementation matrix. On the basis of this, they were ranked as priorities in terms of their implementation order. To eliminate problems, the company should focus on developing a matrix of competences and organizing trainings, and then on introducing standards. An important step in the process of changes in the analysed organization should also be an increase in commitment of the management, which does not see problems but seeks savings.

\section{REFERENCES}

Bendkowski, J. and Matusek, M. (2013). Logistyka produkcji. Praktyczne aspekty, Volume 2, Gliwice: Wyd. Politechniki Śląskiej, p. 35.

Brainstorm Group. Instructional materials.

Furman, J. and Burchart-Korol, D. (2007). Zarządzanie produkcją i usługami. Gliwice: Wyd. Politechniki Śląskiej, p.139.

Kubis, N. (2005). Narzędzia Lean Management. Zagadnienia Techniczno-Ekonomiczne, Volume 50, z. 2-3, p. 292.

Kuczyńska-Chałada, M. and Furman, J. (2016). The process of improvement with the application of lean manufacturing in a steel company. In: METAL 2016: 25th Anniversary International Conference on Metallurgy and Materials, Ostrava: Tanger, p. 1895.

Liker, J.K. (2005). Droga Toyoty - 14 zasad zarządzania wiodącej firmy produkcyjnej świata. Warszawa: Wyd. MT Biznes, p. 36.

Małysa, T., Nowacki, K. and Lis, T. (2017). The correlation between structure of employment and accidents at work in metallurgical enterprises. In: METAL 2017: 26th International Conference on Metallurgy and Materials, Ostrava: Tanger, p. 2244.

Nowosielski, S. (2014). Ciągłe doskonalenie procesów w organizacji. Możliwości i ograniczenia. Prace Naukowe Uniwersytetu Ekonomicznego we Wrocławiu, No. 340, pp. 303-306.

Nogalski, B. (2010). Lean Management. In: M. Czerska and A. A. Szpitter, ed., Koncepcje zarządzania. Podręcznik akademicki, Warszawa: Wyd. C.H. Beck, p. 302.

Piekkari, R. and Welch, C. (2011). Rethinking the Case Study in International Business and Management Research, Edward Elgar, Cheltenham, pp. 27-28.

Skotnicka-Zasadzień, B., Wolniak, R. and Zasadzień, M. (2017). Use of quality engineering tools and methods for the analysis of production processes - case study. In: FEBM 2017: Proceedings of the Second International Conference on Economic and Business Management. In: Advances in Economics, Business and Management Research, vol. 33, p. 240.

Urbaniak, M. (2010). Kierunki doskonalenia systemów zarządzania jakością, Łódź: Wyd. Uniwersytetu Łódzkiego, p. 31.

Wolniak, R. (2013). Metody i narzędzia Lean Production i ich rola w kształtowaniu innowacji w przemyśle In: R. Knosala, ed., Innowacje w Zarządzaniu i Inżynierii Produkcji, Opole: Oficyna Wydawnicza PTZP, p. 524. 